\title{
La poesía dramática de San Juan de la Cruz
}

\section{WASHINGTON DELGADO}

La obra poética de San Juan de la Cruz es muy breve: cinco poemas en estilo renacentista y trece, o quince, en verso octosílabo. De tan pocos poemas, tres destacan nítidamente y se les conoce como los poemas mayores: el Cántico espiritual, la Noche oscura del alma y la Llama de amor viva. A ellos me refiero preferentemente en este trabajo, sobre todo al Cántico y la Noche que me parecen los más característicos de un estilo poético singular e-inimitable.

Mucho se ha estudiado y comentado de la brevísima obra poética de San Juan de la Cruz. Pero como a toda obra clásica (y empleó el adjetivo clásico en el sentido de excepcional, valioso, importante), siempre se la podrá seguir examinando e interpretando. A parte de su alto valor estético, lo que más llama la atención en la poesía de San Juan de la Cruz es sufrescura que ha permanecidó inalterable a través de los años y los siǵlos. ¿Cónfín explican tan Slozana hermosura? La crítica ha observado que su destellante belleza no tiene el esmerado pulimento patente en las poesías de otros escritores inmediatamente anteriores o contemporáneos suyos como Garcilaso, Gutierre de Cetina, Fernando de Herrera o fray Luis de León. San Juan de la Cruz no extrema la lima y la poda en la confección de sus versos, tampoco es un improvisador afortunado o, como dice Dámaso Alonso, un espontáneo que "canta como un pájaro". San Juan de la Cruz muestra una inspiración muy honda, pero también es un artesano del verso que pule y corrige su poesía, aunque sin llegar al extremo de convertirla en un objeto frío o inmóvil. En sus poemas se percibe siempre una vida cálida y temblorosa. Al retocar y hermosear un poema, parece seguir, "avant la lettre", el precepto de Juan Ramón Jiménez: “No le toques ya más que así es la rosa". 
Para explicar la finura y excelencia lírica de San Juan de la Cruz, se han realizado diversos tipos de análisis. Se ha examinado, por ejemplo, su vocabulario, naturalmente es pequeño, tratándose de una obra tan breve. Asombra, sin embargo, que sea muy variado: en sus versos encontramos palabras rústicas o plebeyas (ejido, majadas, adamar, compañas); vocablos cultos (vulnerado, nemoroso, vierdes, bálsamo, esquivo); o deformaciones dialectales (fuerdes, vierdos, perfumea). Esta diversidad, lo repetimos, sorprende en una obra pequeña, pero no explica su originalidad y belleza singular: en otras obras del siglo XVI, encontramos un léxico semejante.

Dámaso Alonso cree que la clave de la poesía de San Juan de la Cruz radica en su rapidez expresiva. Algo hay de verdad en esto, la rapidez del estilo es una característica importante en la poesía de San Juan de la Cruz, aunque no sea la clave absoluta, la llave maestra que abra la puerta de su explicaciốn total. La razón por la cual explica Dámaso Alonso esa rapidez es, en cambio, muy discutible. La atribuye a la escasez de verbos y al predominio de las construcciones nominales ${ }^{1}$. A los ejemplos que aduce para demostrar su tesis, se les puede oponer otros ejemplos contratios: en la primera estrofa del Cántico hay cinco verbos; en la segunda, siete. Doce verbos en diez versos parece abundancia y no escasez. Leo Spitzer, en cambio, explica la Noche oscura por la importancia de los verbos?er tiempo pretérito cuya función es determinante en el"desaffollb del poema y cuyo número va aumentando progresivamente, desde el solitario verbo de la primera estrofa hasta la plétora de cinco verbos en la última².

Otra característica de la poesía de San Juan de la Cruz que contribuye a la formación de la seductora belleza es la luminosidad. Jorge Guillén dice que, incluso cuando describe paisajes nocturnos, sus versos son luminosos y cita este ejemplo deslumbrante: " $¡ \mathrm{Oh}$ noche amable más que la alborada!"”. La luminosidad no se debe al

${ }^{1}$ Dámaso Alonso, La poesla de San Juan de la Cruz. Madrid, M. Aguilar Editor, 142; pp. 165-178.

${ }^{2}$ Leo Spitzer, "Tres poetas sobre el éxtasis (John Donne, San Juan de la Cruz, Richard Wagner)". En: Estilo y estructura de la literatura española, Barcelona, Editorial Crítica, 1980; p. 231 .

${ }^{3}$ Jorge Guillén, "Lenguaje insuficiente. San Juan de la Cruz o lo inefable místico". En: Lenguaje y poesía, Madrid, Revista de Occidente, 1962; p. 101. 58 
cromatismo de los adjetivos, sino al brillo de las imágenes o figuraciones que destacan los objetos alumbrándolos.

Otra característica, apenas entrevista por la crítica y acaso la más importante, consiste en la acabada construcción arquitectónica del poema que comprende y organiza el vocabulario, la sintaxis, las imágenes, versos, estrofas y detalles estilísticos en un conjunto coherente. La poesía de San Juan de la Cruz, aunque guarda semejanzas y paralelismos con la literatura de su época, se ve como un mundo singular, armonioso y autónomo. ¿Cómo podemos definirlo y precisar sus contornos? En el siglo XVı español imperó el renacentismo que puso de moda, y fue uno de sus grandes aportes literarios, la poesía pastoril de inspiración clásica. Los poemas mayores de San Juan de la Cruz están vinculados a esa poesía pastoril renacentista. Muchos contemporáneos suyos (el P. Velasco, las Carmelitas Descalzas de Medina), se refieren al Cántico espiritual como unas canciones en "estilo pastoril". La crítica posterior abunda en el mismo concepto. Pero si se examinan de cerca esos poemas mayores, se ve que lo propiamente pastoril es muy tenue. En la Llama de amor viva apenas notamos la apasionada idealización del amor que coincide, en parte, con los sentimientos de las églogas de Garcilaso y sus continuadores. En la Noche Oscura, de lo genuinamente pastoril, además de la finura sentimental, sólo hay una atmósfera: la noche que acoge a los amantes, el suave viento que acaricia el cuello de "la ămada, las azucenas candorosas. En el Cántico, sí se percibe un mayor número de elementos pastoriles, pero los protagonistas, el Esposo y la Esposa, no son pastores arcádicos: sus palabras y sentimientos son intensos, naturales, espontáneos y se ven bastante alejados de los elaborados y sutiles discursos amatorios de los Salicios, Coridones, Tirsos, Dianas y Galateas de las églogas y novelas pastoriles.

Otra evidencia notoria en el Cántico Espiritual es la bíblica. Si muchos perciben el poema como una égloga renacentista, muchos otros lo ven como una perífrasis o imitación del Cantar de los cantares. Este poema hebreo, sin duda, generó los poemas mayores de San Juan de la Cruz, les proporcionó el tema poético y algunas imágenes. Pero su forma y espíritu son muy distintos de los del Cántico, la Noche y la Llama. El cantar bíblico es torrentoso, robusto, fuertemente sensorial; 
corre por el ancho cauce de los versículos libres, no limitados por la rima ni la medida silábica; se desborda en adjetivaciones y comparaciones abundantes y briosas. La poesía de San Juan de la Cruz es más diáfana y refrenada, se desliza por la vía cuidada y elegante de las liras renacentistas con su alternancia fija de un par de rimas consonantes así como de versos heptasílabos y endecasílabos; no se pierde en tumultuosos símiles o entre aura melodiosa y serena; es intensa pero no desasosegada; su luz es pura, delicada su música. En una palabra: San Juan es clásico; Salomón no lo es.

En los poemas de San Juan de la Cruz hay influencias renacentistas o influencias bíblicas. Ni unas ni otras son absolutamente determinantes. Su papel se reduce a proporcionar unos elementos poéticos que San Juan de la Cruz aprovecha para crear un mundo original y distinto de todo otro mundo físico, histórico o literario. Un mundo terso, perfilado, luminoso y entrañable.

Después de haber establecido que la grandeza poética de San Juan de la Cruz no deriva solamente de su honda inspiración personal o del primor y refinamiento de su estilo sino, principalmente, de su trabajo arquitectónico mediante el cual levantó un mundo poético original, se nos plantean algunas preguntas inquietantes. ¿De dónde provienen las imágenes que sostienen esernundo poético? ¿Cómo se organizan en todo coherente? ¿. Cuáli es lavnaturaleza literaria de esa creación?

San Juan de la Cruz es un poeta claro, directo, asequible. Son éstas características propias de un arte clásico. El arte clásico -recordemos a Spengler- está bajo la égida de Apolo, dios de la luz, la armonía y la razón. Cuando nos preguntamos de dónde provienen las imágenes que despliega San Juan de la Cruz, la respuesta puede parecer paradójica: provienen del inconsciente, ese inconsciente vinculado, más bien, a escuelas o movimientos anticlásicos como el barroco, el romanticismo o el surrealismo. El terso estilo de San Juan puede ocultarnos la profunda raíz irracional de su poesía. Si lo comparamos, por ejemplo, con el iridiscente o intrincado Góngora, San Juan de la Cruz parece diáfano y sencillo. A primera vista se puede tomar a Góngora como un poeta oscuro, profundo, casi incomprensible; sin embargo, es lógico y perfectamente traducible; su lenguaje es alegórico 
y no simbólico. San Juan de la Cruz, en cambio, es intuitivo, realmente profundo e intraducible; su lenguaje se remansa en símbolos, no se pierde en alegorías. Veamos un ejemplo ilustrativo; una de las más brillantes metáforas gongorinas es ésta: "Quejándose venían sobre el guante, los raudos torbellinos de Noruega". La imagen tiene un aire alucinante, casi surrealista; no obstante es muy lógica y racional: se refiere a los halcones o neblíes posados en los guantes de los cazadores que, como se les llevaba encapuchados, piaban semejando gemir o quejarse; estas aves de cetrería se importaban de Noruega y su vuelo, por lo rápido y estruendoso cuando caían sobre su presa, parecía un torbellino. Algo pesadamente y en opaca prosa, pero cabalmente, hemos traducido la diamantina imagen. Pero ¿cómo traducir o explicar las siguientes figuraciones de San Juan, aparentemente tan simples?: "ninfas de Judea"; "aguas, aires, ardores / y miedos de las noches veladores"; "la música callada"; "la soledad sonora"; "pasaré los fuertes y fronteras"; "las ínsulas extrañas". Estas imágenes, o figuraciones, o visiones imaginarias, como su autor las llama, son más luminosas y simples que las de Góngora, pero su luz no borra el misterio que encierran. No sólo son claras y directas, poseen algo conmovedor, producen un extraño embeleso, tocan las fibras más puras del sentimiento estético.

El propio San Juan de la Cruz se daba cuenta de que sus imágenes tenían un origen misterioso $y$ profundo. En Slos comentarios en prosa a sus poemas se "pregintal “QQuién podrar manifestar con palabras lo que las almas amorosas sientes y desean?" Luego, se responde: "Cierto, nadie lo puede; cierto, ni ellas mismas por quien pasa lo pueden; porque esta es la causa que con figuras, comparaciones y semejanzas, antes rebosan (sus canciones) algo de lo que sienten y de la abundancia del espíritu vierten secretos y misterios que con razones lo declaran". En este texto, "manifestar con palabras" equivale a discurso racional y consciente; "figuras, comparaciones y semejanzas" a imágenes o visiones intuitivas o inconscientes; "con razones lo declaran" a los comentarios y explicaciones de las imágenes. La atribución de inconscientes a las "figuras, comparaciones y semejanzas" pudiera parecer arbitraria, pero el mismo San Juan de la Cruz dice que estas

" Gabriel Celaya, "La poesía de vuelta de San Juan de la Cruz". En: Exploración de la poesía, Barcelona, Seix Barral, 1971; p. 162. 
imágenes son las noticias enviadas al entendimiento por dos sentidos interiores, Imaginativa y Fantasía, de acuerdo a sus singulares percepciones, las cuales se producen por dos vías: natural y sobrenatural. Las imágenes naturales, uno mismo las forma dentro de sí "por su propia habilidad"; las sobrenaturales son obra de Dios o, eventualmente, del demonio. Para Gabriel Celaya, esas imágenes no tienen un carácter tan extraordinario como el que San Juan de la Cruz les atribuye por haber identificado lo natural con lo consciente. "Su experiencia de escritor -dice Celaya- al atestiguarle como a cualquier otro escritor le atestigua, que gran parte de su trabajo se realizaba en la sombra y al margen de su deliberada intervención, le llevaba a pensar, de acuerdo con las ideas de su época, que tal actividad no podía ser más que demoníaca o divina. Pero la verdad es que cualquier poesía como la suya, es "sobrenatural en cuanto al modo", dicho sea en términos teológicos, o movida por corrientes inconscientes, dicho sea en términos más modestos.

¿Cómo se organizan esas "visiones imaginarias" para constituir un mundo original, armonioso y autónomo? San Juan de la Cruz se expresa mediante imágenes que provienen de sus intuiciones profundas, temblorosas, preñadas de misterio; pero no es un escritor automático que se deja arrastraf por las corrientes de la inconsciencia. Su poesía no es solamente comunión con el misterio, es también comunicación con los "dermăs. No sólo se ha adentrado en "las profundas cavernas del sentido", para decirlo con un verso suyo. Movido por su amor a los hombres y a las cosas, ha regresado para contar sus experiencias interiores. Gracias a ellas conoce mejor el mundo que lo rodea, lo ama más entrañablemente y quiere hacer partícipes a todos de su sabiduría interior. En su comentario a la Llama de amor viva, escribe: "Esto es el deleite grande de este recuerdo: conocer por Dios a las criaturas, y no por las criaturas a Dios..." Para Gabriel Celaya, esto equivale, en términos artísticos, "a ver lo inconsciente en lo consciente y no al revés". En buena cuenta San Juan de la Cruz es un poeta profundo, pero también un artista consumado; o, como dice Celaya, un obrero-poeta y no un "dexado". Esto significa la recuperación del sentido clásico del arte. La verdadera poesía brota necesariamente del inconsciente, pero se vuelve arte sólo gracias a la acción 
consciente. A esto le llama Celaya "poesía de vuelta" y califica a San Juan como "poeta de vuelta". Por esta vuelta a la consciencia, sus poemas no son una simple sucesión de imágenes, más o menos sugestivas o felices; sus poemas se organizan arquitectónicamente como un todo armonioso, coherente, autónomo.

¿Cuál es la naturaleza literaria de ese mundo construido con arte que hallamos en la poesía de San Juan de la Cruz? Yo diría que es una naturaleza doble. Por una parte es lírica, y así se le ha considerado y estudiado siempre; por otra parte, creo que es teatral. Esta última aseveración puede parecer atrevida y algo desatentada. En primer lugar, antes de entrar a un análisis estrictamente literario, ¿hay algo en la vida del santo que nos indique su afición a las representaciones teatrales o a la lectura de obras dramáticas?

A San Juan de la Cruz no le placía hacer alarde de erudición o de muchas lecturas. Como intelectual universitario, poseía una cultura sólida: latinista versado y buen hebraísta, frecuentaba con destreza la Patrística y tos textos bíblicos. Su dominio del endecasílabo y de estrofas tan exigentes como la lira nos indica que conoció de cerca la nueva literatura renacentista, aunque no sepamos, a ciencia cierta, a qué escritores determinados leyó. Además, como ha señalado abuindäntemente daccrítica y en especial Dámaso Alonso, conocía y gustaba de la literatura popular, heredera de una larga tradición medioeval. Escribió buena parte de su breve obra poética en habituales versos octosílabos, ya en forma de romance asonantados, ya en estrofas consonantes de cuatro, ocho o nueve versos, y aprovechó coplas viejas para glosarlas o remozarlas a lo divino. En el poema Aunque es de noche, bellamente analizado por Dámaso Alonso, llegó a mezclar versificación tradicional con la renacentista. Si no tenemos muchos datos de sus lecturas, y hasta hoy se discute si fue o no fue influido por Garcilaso o por las Confesiones de San Agustín, algo semejante ocurre con su cultura popular. ¿De niño o muchacho, asistió a representaciones teatrales populares, religiosas o profanas y se deleitó al contemplarlas? No lo sabemos, pero nos induciría a contestar afirmativamente no sólo el desarrollo teatral de su época sino, también, una anécdota suya escrita por Jerónimo de San José y recogida por José María de Cossío: 
"Solía el santo en navidad, mandar que sus religiosos hicieren alguna representación piadosa de este misterio. Hallándose, en esta ocasión, en un acto de recreación semejante, sintióse el santo tan enternecido y arrebatado que, tomando en sus brazos un niño Jesús, comenzó a bailar con gran fervor, y en medio de sus júbilos desatados le cantó esta copla:

Mi dulce y tierno Jesús,

si amores me han de matar,

agora tienen lugar.

La copla es popular y antigua, como lo acreditan numerosos testimonios".

La anécdota en la versión de Cossío, reproducida por Dámaso Alonso ${ }^{5}$, nos muestra que la poesía tradicional y popular estaba tan arraigada en el espíritu de San Juan de la Cruz que, en un momento de arrobo místico, se puso a entonar una copla vieja. Y sobre todo, para lo que ahora indagamos, nos hace saber que San Juan se complacía en las representaciones de carácter piadoso. Esta anécdota nos advierte, por último, que la literatura y la vida, la realidad y su representación conformaban para San Juan de la Cruz una bien trabada unidad. Aunque parezca irreverente, no sería descabellado comparar esta anécdota con el episodio de Maese Pedro en el Quijote; allí, el caballero manchego también fusiona la ficción con la vida real e interviene en la representación titiritesca de Maese Pedro para salvar a Melisendra de sus perseguidores. Aparte de esta disquisición literaria, lo cierto es que a San Juan de la Cruz le complacían las representaciones artísticas que acaso abonaron, en su espíritu, un muy fino y escondido talento dramático.

La calidad dramática de los poemas mayores de San Juan de la Cruz ha sido entrevista por la crítica. Dámaso Alonso dice que la primera estrofa del Cántico "está cargada de pasión y de drama, de acción y de sentimiento". Leo Spitzer, en su estudio de la Noche, hablan de "tiempos (verbales) dramáticos" y de una acción que va hacia adelante, pero es Jorge Guillén quien tiene observaciones más amplias y sagaces acerca de la características teatrales del Cántico, la Noche y la Llama. A propósito de la Noche, anota: "La adoración

${ }^{5}$ Dámaso Alonso, ob. cit.; p. 101. 
robusta y graciosa -ventalle de cedros, oriental, bíblico; aire de la almena, medioeval, castellano- no se limita a su papel decorativo y colabora en la acción". Percibimos en esta cita dos elementos vinculados al arte teatral: decorados y acción. Un poco más adelante, hablando del Cántico espiritual, Guillén dice: "Egloga, pues, muy dramática, muy movida, con gradaciones de intensidad que ha analizado magistralmente Dámaso Alonso". En esta segunda cita, al referirse al poema como una égloga, que además califica de "dramática", Guillén alude a su forma en parte dialogada $\mathrm{y}$, al hablar de movimiento $\mathrm{y}$ gradaciones de intensidad, apunta a su desarrollo dramático. Por último, nos dice Guillén: "Los sucesos a lo largo del Cántico y la Llama se presentan ante nosotros en el más efectivo presente. No se trata de un pasado ya concluso que el poeta reconstruye. Nada es ajeno a esta ardiente actualidad que ahora y aquí -en el ámbito del poemadesliza sus presentes actos de amor". Resumiendo, en los poemas mayores de San Juan de la Cruz, los críticos han percibido unos elementos claramente teatrales: decorados, forma dialogada, acción dramática y un tiempo que fluye, avanza, arde o se desliza, es decir que progresa.

Los elementos decorativos se perciben nítidamente en el Cántico y, algo menos acusadamente en la Noche; en la Llama, no existen. Estos elementos han sido tomados de 9 al literatura pastoril, donde no cumplen un papel teatrál sinô pictóricolli son eomo el marco que fija y separa la pintura del espacio que los rodea. Cabe señalar que suelen estar unidos por un conjunto para formar una suerte de paisaje, algo artificioso, que constituye el tópico literario conocido como el "lugar ameno". En el Cántico y la Noche, por el contrario, los elementos decorativos son funcionales, a la manera teatral; no se limitan a un papel decorativo y elaboran una acción, según un pasaje de Jorge Guillén ya citado. No forman un paisaje unitario, van destacando sucesivamente según las necesidades de la acción dramática. Daré tres ejemplos del Cántico, aunque pudiera acopiar muchos más, casi tantos como los objetos que en el poema mencionan, pero cada uno de los tres muestra un tipo distinto de función decorativa. En el primero, la Esposa va por los bosques y espesuras en busca del Esposo cuando, de pronto, divisa una fuente y dice: 
¡Oh cristalina fuente,

si en esos tus semblantes plateados

formases de repente

los ojos deseados,

que tengo en mis entrañas dibujados!

La fuente, como si fuese iluminado por la luz de las candilejas, destaca durante un momento en el paisaje de la búsqueda; su función es la de fijar objetiva y plásticamente algo abstracto y subjetivo: el deseo de encontrar al amado. Segundo ejemplo: producido el encuentro de la Esposa con el Esposo, hay una estrofa que parece o sirve como acotación escénica:

Entrádose ha la esposa

en el ameno huerto deseado,

y a su sabor reposa,

el cuello reclinado

sobre los dulces brazos del amado.

El último ejemplo pertenece al momento anterior de la búsqueda y, en él, los elementos decorativos participan en la acción dramática de una manera aún más estrecha, como si fueran personajes secundarios o comparsas:

\section{Bilopregunta a las criaturas}

¡Oh" bosques y espesuras,

plantadas por la mano del amado!

¡Oh prado de verduras,

de flores esmaltado,

decid si por vosotros ha pasado!

Respuesta de las criaturas

Mil gracias derramando, pasó por estos sotos con presura

y yéndolos mirando,

con sola su figura

vestidos los dejó con su hermosura.

En el Cántico hay numerosos elementos decorativos; en la Noche, no abundan tanto, pero podemos ver como destacan sucesi66 
vamente: la casa sosegada, la escala por donde bajó la amada, un bosquecillo de cedros, las almenas de una torre, las azucenas.

Junto con la decoración, el diálogo, la acción y el tiempo dramático se hallan articulados en el Cántico y, también, en la Noche, donde lo único que faltaría es la forma dialogada. Pero debemos recordar que hay escenas teatrales y aún piezas completas donde figura un solo actor quien, naturalmente no dialoga sino monologa. La Noche nos parece un monólogo dramático. El diálogo se diferencia claramente del relato en tercera persona, propio de la poesía épica, y de la confidencia en primera persona, propia de la lírica. ¿Pero cómo se distingue el monólogo de la confesión lírica personal? Recordemos que la poesía épica es objetiva, en ella se habla de alguien (Aquiles, el Cid, Leopoldo Bloom) quien es el objeto del relato. La poesía lírica es subjetiva, el poeta es el sujeto que expresa sus vivencias personales. La poesía dramática es objetivo-subjetiva, en ella aparecen aparecen unos personajes que son distintos del poeta dramático y constituyen sus objetos literarios; pero estos personajes hablan ellos mismos de sus deseos, percepciones o sentimientos, son los sujetos de lo que dicen. Un monólogo dramático, lomismo que el diálogo es objetivo-subjetivo, quien habla no es el autor sinno su personaje objeto de la ficción dramática y sujeto de lo que dice. Así sucede en la Noche oscura: el poema está escrito en primer perșona ( "yo mirabâ", "yo bien me sabía"), pero quien habla es ella, un personajefefnennino ("salí sin ser notada"), quien habla no es él, el poeta.

En la Llama de amor viva, no solamente la decoración, también el interlocutor ha desaparecido. Apenas queda una acción muy sutil, muy íntima, así como el sentido teatral del tiempo. Detengámonos un momento en este punto. ¿Qué se entiende por sentido teatral del tiempo? La poesía dramática no distingue de la épica y de la lírica por la persona gramatical del discurso y por el tiempo verbal. Lo referente a la persona gramatical acabamos de dilucidarlo. La cuestión del tiempo verbal se puede enunciar más simplemente: en la poesía épica, el tiempo verbal es el pretérito; en la poesía lírica, el presente; en la poesía dramática un presente que corre hacia el futuro. El tiempo del Cántico espiritual es, justamente, éste: un presente que corre hacia el futuro. En la Noche oscura se evoca un pasado 
inmediato que, para el lector o el oyente, se comporta como un presente teatral; no está congelado, inmóvil tal como suele evocársele desde el presente de la poesía lírica, por ejemplo en el soneto de Garcilaso: "Oh dulces prendas por mi mal halladas, / dulces y alegres cuando Dios quería...!" No, en la Noche el pasado evocado es el de una acción que progresa, que avanza hacia un momento posterior, de tal modo que, al leerlo o escucharlo, nos sentimos sumergidos en una acción viva, en una acción que se desarrolla, en una acción dramática. En ambos poemas, el Cántico y la Noche, esa acción es la misma: la Amada que va en busca del Amado hasta encontrarlo y unirse con él. En la Llama de Amor viva, el tiempo dramático se ve menos desarrollado porque el poema describe no la búsqueda sino el momento final del encuentro y la unión íntima de la Amada con el Amado. De todas maneras, el progreso temporal está indicando muy sutilmente: se alude al pasado en el cual se originó la acción dramática ("las profundas cavernas del sentido que estaba oscuro y ciego" o, más, etéreamente, "pues ya no eres esquiva"); y así mismo se insinúa una acción que marcha hacia el futuro ("acaba ya si quieres, rompe la tela de este dulce encuentro").

Hemos señalado cuatro características esenciales del arte teatral: decoración, forma dialogada, tiempo presente que avanza hacia un futuro y acción o conflicto dramático. Las tres primeras las hemos visto claramente erísambladas tanto en el Cántico espiritual como en la Noche oscura y, de una manera más velada, en la Llama de Amor viva. Nos falta referirnos a la acción o conflicto dramático. Hegel ha dicho que en la poesía épica están todas las cosas y en la poesía dramática todos los conflictos. Si bien los conflictos no son muchos (sólo hay treinta y dos situaciones dramáticas posibles), el motivo que los desencadena, el motor que los mueve es bastante variable, cambia según las épocas, según los escritores. Para los trágicos griegos, el motivo determinante de los conflictos dramáticos era el destino implacable que ni los dioses podían torcer. Para Shakespeare y los dramaturgos isabelinos, la maldad que yace en el fondo del alma humana. Para el teatro calderoniano, el severo y yerto código del honor. Para San Juan de la Cruz, para los místicos en general, el motivo fundamental es el amor. 
En su comentario a unos versos de Ovidio según los cuales, antes de que Dios creara el mundo, sólo existía el caos, una masa informe donde estaban todas las cosas en perpetua lid y discorida, Pedro Malón de Chaide, el místico calificando de pintoresco y popular, dice que Ovidio, como gentil y profano, carente del auxiliado divino, desbarró completamente al decir esto porque antes de la creación, las cosas no tenían ser y "quien no tiene ser no puede tener contrariedad con alguna cosa". Malón de Chaide agrega todavía, y esto es lo que atañe más directamente a nuestro tema: "Erró también Ovidio en poner lid y discordia en el caso, antes Platón, en él asentó el amor, como artífice universal de todas las cosas; porque como diremos, por amor se crían. Y por eso lo llaman más antiguo que el mundo y el caos"'.

Para San Juan de la Cruz, el amor lo es todo. En una carta de 1591 a la Madre María de la Encarnación, lo dice: "y donde no hay amor, ponga amor y sacará amor". Giertamente, el amor es el tema predominante en la poesía lírica universal. En el caso de la literatura en lengua castellana, yo destacaría a cuatro poetas excelentes en el desarrollo del tema amoroso: Garcilaso de la Vega, Gustavo Adolfo Bécquer, Pedro Salinas y Pablo Neruda. Garcilaso murió muy joven y su obra poética, casi toda de carácter amatorio, se reduce a un libro pequeño; Bécquer, asímismo, escribió un solo volumen de versos no muy extenso, las Rimas; la obra de Pedro Salinas es más amplia, pero lo mejor de su fina poesía crítica se halla en La voz a ti debida, verdadero tratado poético del amor; Pablo Neruda es el más caudaloso de los cuatro, aunque un solo libro lo representa plenamente, los Veinte poemas de amor y una canción desesperada. Por encima de estos cuatro grandes poetas que condensaron su experiencia o imaginación erótica en cuatro libros relativamente breves, se encuentra San Juan de la Cruz y para sobresalir le bastan sus otros poemas mayores: el Cántico espiritual, la Noche oscura del alma y la Llama de amor viva. Con nada más que ciento ochenta y cuatro versos, San Juan de la Cruz se constituye en el más grande poeta de amor del ámbito español y no sé si de la literatura universal.

${ }^{6}$ Pedro Malón de Chaide, Conversación de la Magdalena. Buenos Aires, Editorial Schapiro (Colección Místicos), 1945; pp. 21-22. 
¿En qué consiste la perfección poética de San Juan de la Cruz cuando desarrolla el tema amoroso? ¿Por qué, con una obra no sólo pequeña sino minúscula, excede a otros poetas de producción más extensa, y más variada y, aparentemente, más rica y vigorosa? Quien mejor ha explicado la naturaleza amorosa de su poesía es Jorge Guillén: "Los poemas -si se les lee como poemas, y eso es lo que son- no significan más que amor, embriaguez de amor, y sus términos se afirman sin cesar humano. Ningún otro horizonte poético se percibe". Lo que nos dice Guillén es que los poemas de San Juan de la Cruz (el Cántico, la Noche y la Llama) no sólo hablan del amor: exclusivamente tratan del amor. Sobre esta base podemos alcanzar cuatro notas por las cuales San Juan de la Cruz se distingue y destaca en la literatura castellana como el poeta del amor por excelencia. La primera nota distintiva es ésta: el amor en la poesía de San Juan es objetivamente total, absoluto, infinito, sin fuertes ni fronteras que lo limiten. Segunda nota distintiva: para otros poetas $-y$ pienso en los más grandes, como los cuatro antes mencionados-, el amor se halla instalado en un mundo hostil o favorable, pero siempre diferente del amor mismo; en San Juan, todo es amor; el mundo, el paisaje, el aire, las cosas, plantas y animales son parte del amor; como dice Guillén: "En los tres poemas no hay más que imágenes: irreales representaciones concretas que forman effelato de un amor". Tercera nota: el amor"descrito ub, chejor dicho,r relatado o, mejor aún, puesto en acción por San Juan de la Cruz es, al mismo tiempo, espiritual y sensual; no hay poesía amorosa en castellano más espiritual, ni siquiera la de Neruda; no hay tampoco más sensual, ni aún la de Pedro Salinas. En la poesía de San Juan, además, sensualidad y espiritualidad forman un todo compacto, sin desequilibrios ni resquicios. La cuarta y última nota distintiva: el amor en la poesía de San Juan no sólo es el más vivo e intenso de todos los amores poéticos, es el que alcanza la mayor plenitud, en una palabra: es el amor feliz. Para otros poetas, el amor es el recuerdo de un bien perdido, o el anhelo de un bien imposible de alcanzar, o un amor de algún modo, aunque sea veladamente, amenazado por la separación, la muerte o el olvido. En San Juan de la Cruz, el amor alcanza la plenitud y allí se queda. En el Cántico y en la Noche, la acción dramática del amor empieza en la soledad de la Amada, se agudiza en la 70 
búsqueda del Amado, se depura en el encuentro de los Amantes y se colma de perfección en la unión amorosa para no acabar jamás:

Quédeme y olvidéme,

el rostro recliné sobre el amado,

cesó todo y dejéme,

dejando mi cuidado

entre las azucenas olvidado.

Lince, 14 de octubre de 1991.

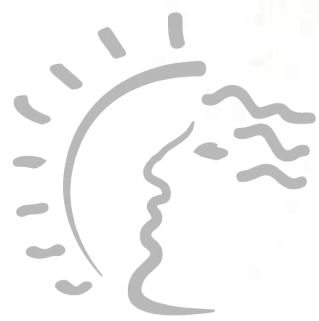

Biblioteca de Letras

"Jorge Puccinelli Converso" 